(c) Religion and Politics Section of the American Political Science Association, 2018. This is an Open Access article, distributed under the terms of the Creative Commons Attribution licence (http://creativecommons.org/licenses/by/ $4.0 /$ ), which permits unrestricted re-use, distribution, and reproduction in any medium, provided the original work is properly cited.

doi:10.1017/S1755048318000573 1755-0483/19

\title{
Islamization by Secular Ruling Parties: The Case of Bangladesh
}

\section{Jasmin Lorch \\ GIGA Institute of Middle East Studies (IMES), GIGA German Institute of Global and Area Studies}

\begin{abstract}
As of yet, Islamization by secular ruling parties has hardly been investigated in depth. To bridge this gap, the present article reviews the existing literature on Islamization, synthesizes the scattered existing theoretical insights on Islamization by secular actors and applies them to the case of Bangladesh. It argues that, especially when they act in conjunction, three main conditions can drive secular rulers to Islamize public policy: first, the rise of Islamist social movements; second, fierce political competition; and third, (semi-)authoritarian rule. Focusing on the current Awami League (AL) government, the article shows how these three factors have interacted to produce a top-down process of state-led Islamization in Bangladesh.
\end{abstract}

In December 1971, Bangladesh was established as a secular state based on the country's ethno-linguistic Bengali identity (e.g. Siddiqi 2011, 18), following a war of independence against Pakistan in which between one and three million Bangladeshis were killed (Cordon 2007, 14). The Awami League (AL) that led the independence struggle is a secular party, whose constitution pledges "[t]o build a [s]ecular, democratic society and state-system imbued with the spirit of Liberation War" (AL constitution). In the 2008 elections, which it won decisively, the AL appealed to secular voters (Jahan and Shahan 2014, 432).

Eight years into the AL's continued rule, however, the situation looks different. In February 2016, law enforcement arrested the editor of

The field research for this article was funded by the Deutsche Forschungsgemeinschaft (DFG) (grant number: DFG FU 243/9-1, AOBJ 612034).

Address correspondence and reprint requests to: Jasmin Lorch, GIGA Institute of Middle East Studies (IMES), GIGA German Institute of Global and Area Studies, GIGA Berlin Office, Friedrichstraße 206, 10969 Berlin, Germany. E-mail: jasmin.lorch@giga-hamburg.de 
Islam Bitorko (Debate on Islam), a book that includes a provocative chapter on Muslims and sex, on grounds that it hurt religious sentiments and closed his stalls at the annual Ekushey Book Fair in Dhaka (Express Tribune 16 February 2016). One year later, the Bangla Academy, the national academy for the promotion of the Bengali language and the convener of the fair, announced that it would alert the security forces to any "blasphemous" books advertised at the event (Dhruba 2017). In January 2017, the government launched new editions of schoolbooks, which featured more references to religious symbols and from which 17 poems that Islamic conservatives had despised as "atheist" had been removed (Barry and Manik 2017). Moreover, the AL government has massively enhanced its support of mosques and madrassahs (Islamic education institutions). ${ }^{1}$ Thereby, the AL is replicating the policy of its arch-rival, the Bangladesh Nationalist Party (BNP). When it was in power from 2001 to 2006, the BNP introduced various measures that benefitted Islamist parties and conservative madrassahs (ICG 2006, 5, 19ff.; Riaz 2007a, 39ff.). In its campaign for the 2008 elections, which it lost, the BNP used the slogan "save Islam and the country" (Daily Star 23 December 2008).

Why do secular ruling parties Islamize? Using the example of Bangladesh, this article shows that, especially when they act in conjunction, three main conditions can drive secular rulers to Islamize public policy: first, the rise of Islamist social movements; second, fierce political competition; and third, (semi-)authoritarian rule. It enriches the debate on Islamization in Bangladesh, which remains severely understudied (for exceptions, see Riaz 2007a; 2007b; 2014; Riaz and Fair 2011; Kabir 2015; Fair, Hamza, and Heller 2017). This research lacuna is highly problematic, not least in view of the increase in terrorist attacks that the country has recently experienced, most notably the July 2016 attack on the Holey Artisan Bakery café in Dhaka that was claimed by the Islamic State (Fair, Hamza, and Heller 2017, esp. 622-624; Kugelman and Ahmad 2017).

In addition, analyzing the Islamization efforts of secular ruling parties in Bangladesh contributes to the broader theoretical debate on Islamization. Specifically, works that tackle the Islamization of public policy usually concentrate on Islamization by Islamist actors (Buehler 2013, 63), such as the establishment of an Islamic state by the Islamic revolutionary movement in Iran (e.g. Martin 2007), or the Islamization efforts undertaken by Islamist parties in Egypt and Tunisia after the Arab Spring (e.g. Donker 2013; Ghanem 2013). Moreover, the few isolated works that deal with Islamization by secular politicians often limit themselves to studying countries such as Egypt, Malaysia or Algeria, where secular 
incumbents have faced Islamist contenders with strong support at the ballot boxes (e.g. Ismail 2006; Kubicek 2015, 83-116). Contrary to this, the Bangladeshi case provides insights into the motivations that may drive secular ruling parties to Islamize in the absence of strong Islamist opposition parties. ${ }^{2}$

Furthermore, it contributes to the broader theoretical debate on the extent to which ideational factors and religious ideas (Gill 2008, 7-9, 31-32, 57-59), the competition between secular and religious actors in society (Fox 2015, esp. 32-35), or political elite interests (Fox 2015, esp. 36-38; 132, 239-246; Gill 2008, 7-9, 31, 32, 57-59) drive religion policy-making. Based on extensive quantitative data, Fox (2015) has recently argued that states are becoming more entangled with religion and that this also includes states that officially endorse secularism. Many of the increasing forms of entanglement he identifies can be observed particularly in Muslim-majority countries (Fox 2015, 98-104, $118,133-134,214-216)$. Fox traces these trends to an ongoing competition between secular and religious actors in society in which the latter currently have "the upper hand" (Fox 2015, 65). However, the exact motivations of (secular) state leaders to get involved in religion cannot be clearly determined by quantitative studies (Fox 2015, 104), and Fox himself admits that the practical interests of political elites sometimes play an important role in religion policy-making (Fox 2015, 239-246).

Against this backdrop, an in-depth study of Bangladesh that carves out the motivations of secular ruling parties to engage in Islamization is theoretically relevant, as the country presents an interesting puzzle with regard to the relationship between the social role of Islamist forces and religion policy-making. Specifically, Bangladesh has often been hailed as a textbook example of the reconcilability of Islam and secular democracy (Fair, Hamza, and Heller 2017, 622), and, since 2001, the vote share of Islamist parties has never been above 6.3\% (Riaz 2014, 163-165), indicating that the social impact of Islamist forces is low. Nevertheless, consecutive secular-party governments have apparently felt compelled to accommodate diverse Islamist forces, raising the question of why this has been the case.

The article synthesizes and expands the scattered theoretical insights on the conditions driving secular parties to support Islamization that exist in the literature. Specifically, while existing case studies have discussed the role of Islamist movements, political competition, and (semi-)authoritarian rule in spurring Islamization by secular rulers, they have neither gauged the relative explanatory potential of these factors nor linked them in any 
systematic way. To bridge these gaps, this article first connects these three factors to Fox's (2015) and Gill's (2008) theoretical considerations on the drivers of religion policy-making and then tests and refines the resulting explanations of Islamization by secular rulers with rich qualitative data from Bangladesh. The empirical findings presented build on 51 interviews conducted from January to March 2017 with representatives of the AL and the BNP, Islamist forces, civil society actors, as well as Bangladeshi and international experts.

\section{ISLAMIZATION BY SECULAR RULERS: EXISTING THEORETICAL INSIGHTS}

Drawing on Ismail (2006, esp. 1-4, 22-26), this article defines Islamization as a process whereby political practices and public policy are increasingly (re-)ordered according to Islamic rules and symbols. As such, Islamization can occur in different policy domains and can be driven by both Islamist and secular actors. ${ }^{3}$ Islamist actors, on the other hand, are defined more narrowly as political actors who (permanently) place their own ideals, aims, and demands into an Islamic frame of reference (Asseburg 2007, 9). Secular political actors are defined as actors who ideologically advocate the avoidance of state involvement in religion (Fox 2015, 8, 28; Moshin 2004, cited in Kabir 2015, 60).

Case studies on various Muslim-majority countries, including Indonesia (e.g. Freedman 2009; Buehler 2013), Malaysia (e.g. Abott and GregoriosPippas 2010; Camroux 1996; Liow 2004), Pakistan (e.g. Malik 1986; Khan 2013; Butt 2016), Morocco, Algeria, and Egypt (e.g. Parmentier 1999; Ismail 2006; Hamid 2014), show that secular ruling parties sometimes engage in Islamization. The resulting state-led Islamization efforts can include the introduction of blasphemy laws, an Islamization of the state-run education system through textbook and curriculum changes, or increased state support for madrassahs (Malik 1986, 598-599; Camroux 1996, 856-863; Parmentier 1999; Liow 2004, 194-97; Khan 2013, 147).

\section{Islamic Revivalism and Islamist Social Movements}

According to the "competition-perspective" proposed by Fox (2015, esp. 32-35), state religion policy is predominantly the result of struggles between secular and religious actors in society. Similarly, several case studies on Muslim-majority countries point to the role that "bottom-up 
pressures" (Abbott and Gregorios-Pippas 2010, 148), such as the revival of Islamic orthodoxy or Islamist social movements, can play in driving secular rulers to promote Islamization (e.g. Ismail 2006; Abbott and Gregorios-Pippas 2010; Buehler 2013; Butt 2016). For instance, studies on Egypt show how an increase in religious orthodoxy among the population has impacted the religion policies of successive secular regimes (e.g. Ismail 2006, 58-81).

Specifically, where secular governments are faced with the growing influence of private mosques or madrassahs, they may expand the religious infrastructure of the state and reinforce the regulation of religion. However, government measures such as the state-led construction of mosques or the enlargement of religious bureaucracies may reinforce the Islamic characteristics of the state, as cases as different as Malaysia (e.g. Abbott and Gregorios-Pippas 2010), Algeria, and Morocco (Parmentier 1999) show.

However, state-led Islamization efforts can not only result from an increase in Islamic orthodoxy in the wider society but also from the pressure created by rather exclusive Islamist movements. This is illustrated by both Buehler's (2013) work on Indonesia and Butt's (2016) analysis of Pakistan. Testifying to a lack of popular support for an Islamist agenda, the vote share of Islamist parties has remained low in both countries. Nevertheless, in both cases, secular rulers have made significant concessions to well-organized, but largely unrepresentative Islamist social movements. For instance, Islamists in Pakistan have extracted many policy concessions from secular governments because of their strong capability to organize street protests, which results from their control over dense networks of Deobandi (or Qawmi) madrassahs (Butt 2016).

Similarly, theoretical research points to the strong ability of religious groups to "quickly mobilize collective action," such as protests, owing to the shared values and regularized meetings of their members, and the latter's unconditional readiness to follow their religious leaders (Gill 2008, 51). Evidently, these characteristics hold true regardless of the broader social representativeness of the respective religious groups.

However, the question arises under which political conditions secular governments are more-or less-likely to respond to the pressure created by Islamist movements.

\section{Political Competition}

Case studies on countries as different as Morocco and Algeria (Parmentier 1999), Egypt (Ismail 2006, 58-81), and Malaysia (e.g. Liow 2004; 
Kubicek 2015, 83-116) suggest that one of these conditions is when Islamist movements have political representation through strong Islamist opposition parties. For instance, consecutive secular regimes in Egypt that were challenged by the Muslim Brotherhood, which participated in elections, engaged in diverse Islamization efforts (Ismail 2006, 58-81; Hamid 2014, 171-177, 207, 222). Similarly, in Malaysia, the United Malays National Organization (UMNO) promoted state-led Islamization to counter the electoral challenge of the Islamist Parti Islam Se-Malaysia (PAS) (e.g. Camroux 1996: esp. 856-857; Kubicek 2015, 83-116), leading Liow (2004) to speak of an "Islamization race" between the UMNO and the PAS.

Secular ruling parties may try to weaken their Islamist contenders by co-opting rival Islamist actors. In Malaysia, for example, the UMNO co-opted Anwar Ibrahim and other leaders of the Malaysian Islamic Youth Movement (ABIM), an Islamist movement formerly close to the PAS, into the state (e.g. Camroux 1996, 859-860; Kubicek 2015, 99102), increasing the Islamization of the bureaucracy (Abbott and Gregorios-Pippas 2010).

However, state-led Islamization may prompt Islamist opposition parties to adopt more orthodox stances to distinguish themselves. Thus, the influential "inclusion-moderation hypothesis," which states that Islamists grow more moderate and democratic when they participate in formal political processes (Schwedler 2011), may not hold in contexts of fierce political competition (Mecham and Hwang 2014, 10-11).

Generally, the motivations of secular rulers to co-opt—or make concessions to-religious groups can often be traced not only to the former's acknowledgement of religion's social influence (Fox 2015) but also to their practical interests. In particular, this includes the desire of secular state leaders to safeguard their "political survival" (Gill 2008, 9, 47-57; see also Fox 2015, 36, 38, 239-246), which can also be threatened by secular contenders. Gill $(2008,51,53-55)$ argues that in the context of fierce competition among secular politicians, secular rulers may "cut deals" (Gill 2008, 54) with religious groups that might otherwise strengthen their rivals. Fox $(2015,242,245)$ likewise hints that battles between secular politicians may sometimes influence religion policymaking more than the secular-religious competition.

Accordingly, Buehler's (2013) analysis of Indonesia traces how secular rulers in several Indonesian provinces passed most of the country's Sharia (Islamic law) legislation, owing to ties they had forged with radical Islamist movements and power brokers in the context of fierce electoral competition among secular politicians. 


\section{(Semi-)Authoritarianism}

In addition, many case studies show that secular rulers frequently Islamize when they lack democratic legitimacy (Malik 1986; Parmentier 1999; Freedman 2009, 113-115, 122-123; Khan 2013; Kubicek 2015, 83116) and, thus, attempt to use Islamization as an authoritarian legitimation strategy. In Pakistan, for instance, military ruler Zia-ul Haq engaged in farranging Islamization efforts to compensate for his lack of electoral legitimacy (Malik 1986, 594-605; Khan 2013). Similar tendencies have been observed in authoritarian Algeria and Morocco (Parmentier 1999, esp. 36-41), or semi-authoritarian Malaysia (Camroux 1996, 856-863; Freedman 2009, 106; Liow 2004, 185).

Authoritarian government practices are not incompatible, but, in fact, often go hand in hand with political competition, as the literature on "semi-authoritarian" (Ottaway 2003) or "competitive authoritarian" (Levitsky and Way 2002) regimes shows. Specifically, while "competitive authoritarian regimes" create a highly uneven playing field, they continue to face political oppositions that can potentially threaten their survival (Levitsky and Way 2002). While such regimes rely on repression to safeguard their rule, extensive onslaughts on (semi-)democratic institutions, such as elections, can spark resistance that may also bring them down (Levitsky and Way 2002, 58-59).

In such a context, secular incumbents in Muslim-majority countries may malign their political opponents as promoting "wrong" or "extremist" versions of Islam, as the Malaysian case shows (Noor 2003, cited in Kubicek 2015, 102). Concurrently, the repression of secular opposition forces may strengthen Islamist groups in various ways (Camroux 1996, 856; Freedman 2009, 113). Moreover, authoritarian regimes often also repress or try to divide and rule Islamist groups (Camroux 1996, esp. 863-865, 868; Freedman 2009), a situation that may strengthen orthodox organizations. In Indonesia, for instance, the Suharto regime forged alliances with hardline Islamists to counter moderate Islamic groups that demanded democratization (Freedman 2009, 114-117, 124).

\section{ISLAMIZATION BY SECULAR RULERS IN BANGLADESH: FROM PAST TO PRESENT}

The preamble of Bangladesh's 1972 constitution, which was passed under AL leader Sheikh Mujibur Rahman, enshrined secularism, democracy, 
nationalism, and socialism (d'Costa 2007, 226). In 1977, however, the military regime of General Ziaur Rahman removed the principles of socialism and secularism, replacing them with the invocation of faith in Allah. Zia also abolished the ban on religious politics, leading to the reconstitution of the Islamist party Jamaat-e-Islami (JI) that had sided with Pakistan during the war and whose militias have been implicated in large-scale massacres. Furthermore, Zia and his BNP coined the concept of Bangladeshi nationalism that emphasizes the Muslim characteristics of the nation and thus differs from the AL's Bengali nationalism that builds on the country's ethno-linguistic identity. In 1988, the military regime of General Hussain Muhammad Ershad, who founded the Jatiya Party (JP), made Islam the state religion. Both Zia and Ershad relied on religious rhetoric, promoted the building of mosques and allowed conservative madrassahs and Islamic welfare associations to grow and receive funding from the Middle East. ${ }^{4}$ The literature is unanimous that both military dictators used Islamization as a legitimation strategy to compensate for their lack of electoral legitimacy (e.g. Milam 2007; Siddiqi 2011, 12, 19; Jahan and Shahan 2014, 427, 429). Ahamed and Nazneen (1990, esp. 807-808) conclude that the "upsurge in Islamic activities" under military rule was "not due to Islamic revivalism" but "power politics."

The parliamentary period from 1991 to 2006 was marked by fierce political competition between the AL and the BNP, now led by Sheikh Hasina, the daughter of Sheikh Mujib, and General Zia's widow, Khaleda Zia, respectively. When in office, both parties staffed the administration with their own loyalists, while repressing the opposition. Each time elections were held, the AL and the BNP alternated in power and former opposition parties took revenge on their outgoing rivals through violent attacks (Lorch 2014). When in the opposition, both parties used large-scale, violent demonstrations to exert political influence. ${ }^{5}$

The rivalry between the parties was furthered by Bangladesh's firstpast-the-post system, which led both the AL and the BNP to co-opt Islamist forces to gain power. In 1991, the BNP relied on the support of the JI to assume government, while in 1996 the JI joined the AL's protest movement to oust the BNP. From 2001 to 2006, the BNP led a coalition government that included the JI and the Islami Oikya Jote (IOJ), a federation of small Deobandi parties. Their role as "kingmakers" enabled the Islamist parties to expand their political influence, although their combined vote share declined (Karim and Fair 2007, 1, 5; Riaz $2007 \mathrm{a}, 2014$ ), from $14,41 \%$ in 1991 , to $9.7 \%$ in 1996 , and $4.97 \%$ in 2001, respectively (Riaz 2014, 163). 
During the BNP-led coalition government, JI representatives headed the Ministry of Social Welfare, as well as, temporarily, the ministries of agriculture and industry, although the party received only $4.29 \%$ of the vote in 2001 (Riaz 2014). Owing to the influence of the JI and the IOJ in the ruling coalition, the government initiated steps to grant official recognition of the degrees of Qawmi madrassahs (Masud 2006), orthodox education institutions that mostly adhere to the Deobandi faith and operate largely outside state control (ICG 2006, 13-14; Riaz 2007b, 37-40). Moreover, the JI used its time in office to establish its cadres in the administration and the education system (Riaz 2007b, 27).

As Riaz (2014, esp. 156) convincingly argues, due to their kingmaker role, the inclusion of Bangladesh's Islamist parties into the political system did not lead to their moderation. Before the 2008 elections, for instance, the JI removed a clause that postulated the "sovereignty of Allah," and thus contradicted the democratic principle of popular sovereignty from its party constitution to meet the requirements of the Election Commission (Riaz 2014, 169; Kabir 2015, 72). A JI leader explained, however, that this change had been "absolutely strategic" and did not alter the party's belief in divine rather than popular sovereignty. ${ }^{6}$ Similarly, a senior JI adviser claimed that he had convinced the JI's leaders to drop the clause, telling them that "God's sovereignty does not depend on people's recognition-so just forget about it." 7

Furthermore, the period from 2001 to 2006 was marked by a rise in terrorist activities, including over 400 countrywide bombings. Many experts hold that the lines between militant groups and above-ground Islamist parties were blurred, as several members of terrorist organizations were former cadres of the JI (e.g. ICG 2006, 18f.; Riaz 2007a, 25-26; Ahsan and Banavar 2011, 73-74).

Moreover, since the early 1990s, both the AL and the BNP have repeatedly relied on religious symbolism and downplayed the country's secular traditions (Jahan and Shahan 2014). Specifically, between 1991 and 2006, the BNP's electoral campaigns stressed the party's Islamic credentials, while portraying the AL as "anti-Islamic." While the AL branded both the BNP and the JI as "anti-liberation force(s)," it refrained from running on an explicitly secular agenda in its 1996, 2001, and 2006 campaigns (Jahan and Shahan 2014, 430-432, 433-435). Moreover, it sought to prove that it was not "anti-Islamic." In 2006, the AL forged an agreement with the orthodox Deobandi party Khilafat Majlis, promising that if it came to power it would not pass any law that went against the Koran. ${ }^{9}$ 
According to Jahan and Shahan $(2014,432)$, the proneness of the AL and the BNP to use religious rhetoric was mainly due to the fact that from 1991 to 2001, elections were always won by the party aligned with the JI. Based on field interviews, they show, however, that the decision of voters to vote for either the AL or the BNP was often driven by the voters' evaluation of government performance in secular matters, such as consumer prices, and, hence, by a strong anti-incumbency factor, rather than religious preferences (Jahan and Shahan 2014, 435-436). Consequently, they conclude that the AL's and the BNP's religious campaign tactics rested on a "false premise" (Jahan and Shahan 2014, 428) and usually failed to increase the vote share of either party.

In its 2008 election campaign, the AL returned to a secular agenda (Jahan and Shahan 2014, 432), promising to fight militancy and try the Islamist war criminals, a change that can likely be traced to the widespread popular frustration about the BNP's failure to contain terrorism during its rule (see also Jahan and Shahan 2014, 435). The BNP and its "nationalistIslamist" coalition, which included the JI and the IOJ, campaigned on the slogan to "save Islam and the country" (Daily Star 23 December 2008). The AL won the elections decisively, while the BNP suffered a heavy defeat. The combined vote share of all Islamist parties amounted to $6.27 \%$ and, thus, remained low but constant (Riaz 2014, 165).

As Riaz details, this percentage is consistent with both the 2008 preelection poll of Nielsen and the Daily Star and the 2005 World Value Survey that recorded popular support for an Islamic state at only $7 \%$ and 9\%, respectively (Riaz 2014). However, most Bangladeshis are personally religious. In a 2016 survey conducted by Nielsen-Bangladesh, $74 \%$ of the respondents said that religion was "very influential" (39\%) or "somewhat influential" (35\%) on their "day-to-day views and opinions" (BSoPO 2016, 33). As of 2013, electoral support for the JI had further dropped according to a 2013 Nielsen/Democracy International survey, the latest available opinion poll on this matter (New Age 19 September 2013).

Nevertheless, widespread personal religiosity provides a social context in which issues of "Islamic sensibility" (Kabir 2015, 69) and religious "taboos," such as criticism of the Prophet, ${ }^{10}$ can be mobilized against incumbent governments (Kabir 2015, 69-71). ${ }^{11}$ This explains the AL's above-mentioned fear of being seen as "anti-Islamic." Given the low level of popular support for the Islamist parties, however, the AL's and the BNP's kowtows to Islamist forces are excessive, leading a local university expert to conclude, 
It's the kind of secular politics [...] we have that provides space for these [Islamist] forces. [...] They [the main political leaders] are starting their election campaigns by going to shrines or going to Saudi Arabia. [...] If you want to do politics here, you don't mess with faith. [...]. [But] secular politicians have over-used the religion card. [...]. The political parties $[\ldots]$ will continue to make compromises, but [...] society is secular. 12

Since 2009, the AL government has severely repressed the BNP and the JI (e.g. ICG 2012). In June 2011, it abolished the "caretaker system" that guaranteed the conduct of national elections under a non-partisan interim government. After staging violent demonstrations in which over 300 people were killed, the BNP boycotted the 2014 polls. The JI was unable to run because in 2013 the High Court had cancelled its registration, arguing that the party's charter went against Bangladesh's secular constitution (Lorch 2014). For the first time since 1991, a party has hence extended its winner-take-all-politics to a second term, leading to an unprecedented concentration of power in the hands of the AL. ${ }^{13}$ The 2018/2019 elections will likely decide whether Bangladesh's political system retains veritable democratic characteristics or becomes predominantly authoritarian. The BNP has threatened to boycott the polls again unless the caretaker system is reinstated. In this case, however, it would lose its registration, leaving the country without any veritable opposition party. ${ }^{14}$ A leading BNP functionary stated that if the 2018/2019 polls were unfree, the BNP-led coalition would unleash large-scale violence and "paralyze the whole country." 15 Concurrently, however, many AL leaders feel that they cannot leave power anymore because in the case of a government change, they would face unprecedented reprisals by the BNP and its allies. ${ }^{16}$

\section{Islamization under the AL: Concessions to an Islamist Social Movement}

At the beginning of its tenure, the AL pushed secularization. In 2011, it passed a National Women Development Policy that was fiercely opposed by Islamist actors and reinstated secularism into the constitution (Islam 2016, 65-66). Both of these moves were protested by the hitherto unknown Hefazat-e-Islam, an orthodox Deobandi movement rooted in the country's Qawmi madrassahs (Kabir 2015, 69). ${ }^{17}$

The Deobandi ideology is an orthodox scholastic tradition within revivalist Sunni Islam. It derives from the Darul Uloom Deoband School in 
India and focuses on spreading religious education through madrassahs (Hashmi 2016, 142). Generally, the Deobandi faith emphasizes (blind) imitation (taqlid) (Kabir 2015, 57) and thus differs from the JI, the other major revivalist movement in Bangladesh that allows some measure of individual reasoning (ijtihad). The JI is sometimes compared with the Muslim Brotherhood and draws on Maududi who emphasized control of the state as the main means to change society (Kabir 2015, 51, 68-73). ${ }^{18}$ The Deobandis and the JI concur, however, in their rejection of the mystic and syncretistic traditions associated with Sufi Islam (Kabir 2015, 52; Hashmi 2016, 142).

A senior leader of Hefazat described the movement as a network of several Deobandi groups whose agenda is to protest any "anti-Islamic" activities, including both government and social activities. While Hefazat sought to bring society and politics in line with the Sharia, he explained, its aim was not to gain power or to topple (or support) any government. At some point, however, Hefazat's main leader, Shah Ahmad Shafi, had decided to establish relations with all (Deobandi) Islamic forces, including various Islamist parties, to build a platform of likeminded people across Bangladesh. ${ }^{19}$

While the AL did not make any concessions to Hefazat in 2011, this changed from 2013 onwards. In March 2010, the AL government had established the International Crimes Tribunal (ICT) to try the war crimes committed by Islamist militias in 1971. Starting from early 2013, the tribunal announced verdicts, most of which targeted leading JI representatives. In February 2013, the ICT's issuing of a life sentence against the JI's Assistant Secretary General Abdul Quader Mollah sparked massive protests by the Shahbag movement, a social movement led by secular activists and bloggers, who demanded the hanging of Mollah, a revival of the spirit of the liberation war and a total ban of the JI (Kabir 2015, 68-69). ${ }^{20}$

The Shahbag movement triggered large-scale counter-demonstrations by Hefazat (Kabir 2015, 68-69), ${ }^{21}$ which branded the Shahbag activists as "anti-Islamic" and "atheist." Moreover, it now began to raise 13 demands, including the passage of a blasphemy law, the scrapping of the women development policy and making Islamic education mandatory (Kabir 2015, 70). ${ }^{22}$ In early May 2013, the Hefazat's demonstrations blocked entire parts of Dhaka (Islam 2016, 64, 83, 227).

The mobilizing capacity of Hefazat was huge and the movement reportedly brought around 500,000 followers to Dhaka (Bouissou 2013), posing a serious challenge to the government's stability. ${ }^{23}$ According to a UN 
representative, leading AL members were "terrified" by the magnitude of the protests. ${ }^{24}$ Notably, however, the vast majority of the protesters were faculty members and students of Qawmi madrassahs controlled by Hefazat leaders, many of whom were bussed to Dhaka from Hefazat's stronghold in Chittagong (BBC 6 May 2017), rather than common people joining the movement to support its demands. ${ }^{25}$ As an expert who works with these madrassahs explained, Qawmi madrassah students are highly dependent on their religious teachers/leaders (mullahs) and would follow them whatever they say. Thus, if the mullahs told them to come to the streets, they would stand "like an army." One average Qawmi madrassah, he estimated, could bring about 2000 followers into the streets, while the mullahs, who led these madrassahs, had dense personal networks among themselves. ${ }^{26}$ Thus, Hefazat has a "ready network," enabling the movement to quickly mobilize its members for demonstrations, which makes it an important player in Bangladesh's street and power politics. ${ }^{27}$ Concurrently, however, many local experts are convinced that the movement does not represent vast sections of the population. ${ }^{28}$ This contradicts foreign diplomats and aid experts who view the rise of Hefazat as a sign of an increase in orthodox tendencies in the wider society, or even as an expression of popular support for Islamic fundamentalism. ${ }^{29}$

In particular, the AL government was afraid of the emergence of a united mobilizational front of the opposition. Hefazat and the JI cooperated during the 2013 protests (Kabir 2015, 51, 68-73), ${ }^{30}$ and, in May 2013, the BNP sought to exploit the demonstrations to topple the AL, calling on ordinary people to join Hefazat (Islam 2016, 64, 83, 227). Significantly, Hefazat, the JI, and the BNP all portrayed the Shahbag movement as being supported by the AL government, while, concurrently, attempting to mobilize religious sensitivity by depicting the Shahbag activists as "atheist" (Kabir 2015, 69-70). ${ }^{31}$ A Shahbag leader who was simultaneously a main leader of the AL's student wing, the Chattra League (CL), recalled that the BNP's chairwoman Khaleda Zia had stated publicly that "these people [the Shahbag activists] are atheist." Thereby, he lamented, the BNP was "very planfully [sic!]" playing "the religion card" and trying to make the religious people view the Shahbag activists as infidels [kafir]. ${ }^{32}$ According to a terrorism expert close to the AL, this fueled the AL's fear of being viewed as "anti-Islamic" that is grounded in the party's experience of losing the 1991 and 2001 elections. ${ }^{33}$ In particular, the party was afraid of being seen as anti-Muslim if it cracked down on the protests of the religious men, ${ }^{34}$ given that, as a local expert explained, while most 
Bangladeshis do not want conservative religious leaders to get involved in politics, "they respect them in their mosques." 35

In this situation, the AL tried to negotiate with Hefazat (Islam 2016, 64), and the Directorate General of Forces Intelligence (DGFI) reportedly intervened to protect Shafi, fearing that if he was killed in clashes, Hefazat's supporters might run amok. As Hefazat's leaders refused to give in, however, the government finally dispersed the demonstrations with the minimal force possible. ${ }^{36}$ Subsequently, the AL government adopted a mixed strategy, consisting of both pressure and appeasement. It infiltrated Hefazat with security forces and put its followers under surveillance by the intelligence agencies. ${ }^{37}$ Similarly, the movement has faced serious repression and harassment. ${ }^{38}$ Concurrently, however, the AL also established communication channels to Hefazat and has dialogued with its leaders over their demands. ${ }^{39}$ In early 2017, one of Hefazat's senior leaders emphasized that they "negotiate[d]" and "compromise[d]" with the government to be able to survive, not because they wanted to. As part of the current compromise between the two sides, he added, the government allowed Hefazat to keep operating, while the movement refrained from staging any major demonstrations. ${ }^{40}$

According to local experts, the previously mentioned textbook changes constitute explicit concessions made by the AL government to Hefazat. ${ }^{41}$ Correspondingly, government authorities imposed the aforementioned restrictions against the editor of Islam Bitorko at the Ekushey Book Fair, following threats by the Islamist party Khilafat Andolan, whose membership overlaps with that of Hefazat, ${ }^{42}$ to storm the event (Daily Star Lebanon 16 February 2016). Similarly, in May 2017, "Lady Justice," the statue of a woman wearing a sari, sword, and scale was removed from the premises of the Supreme Court, following protests by Hefazat (Kugelman and Ahmad 2017).

The AL has sought to combine its concessions to Hefazat with efforts to increase state control over the Qawmi madrassahs. ${ }^{43}$ In April 2017, the Ministry of Education ordered that the Dawra-e-Hadith certificate of Qawmi madrassahs be recognized as an equivalent to a master's in Arabic and Islamic studies, completing a process initiated by the BNP during its last tenure. The formulation of the madrassah's curricula and the award of Dawra-e-Hadith certificates are to be centralized under a committee headed by Hefazat's leader Ahmad Shafi, which, however, reports to the Ministry of Education. While the measure establishes some minimum government control over the Qawmi madrassahs, it will Islamize the bureaucracy, as it will allow many Qawmi madrassah 
graduates to apply for positions in the civil service (Bdnews24 13 April 2017). Simultaneously, the government is extending its own religious bureaucracy. As of early 2017, it reportedly planned to spend around 70,000 million taka on constructing a huge mosque with an adjunct Islamic studies center in Dhaka, along with similar, smaller mosques and study centers at all tiers of the local government system around the country, to centralize religious oversight. ${ }^{44}$

\section{Islamization under the AL: Political Competition and the Co-optation of Islamist Forces}

With the 2018/2019 elections drawing closer, the AL has enhanced its efforts to co-opt Hefazat. While the latter is not a political party in itself, it involves many Islamist leaders who simultaneously lead small Deobandi parties, such as Khilafat Andolan, Khilafat Majlis, or parties assembled in the IOJ. ${ }^{45} \mathrm{~A}$ senior BNP leader explained that before 2013, Hefazat had been aligned with the BNP's electoral alliance through the IOJ, which had formed part of the BNP-led coalition government. ${ }^{46}$ Accordingly, the BNP supported Hefazat's 2013 protests, and Hefazat and the BNP also coordinated their anti-government demonstrations surrounding the 2014 elections. Recently, however, the AL has put enormous pressure on Hefazat and the Deobandi parties within it to make them align with its own electoral front. ${ }^{47}$ In early 2017, a leader of both Hefazat and Khilafat Andolan elaborated that the government had just revived 43 criminal cases filed against Hefazat followers during the 2013 demonstrations and was also threating to take two big madrassahs, including the Lalbagh Madrassah in Dhaka, away from the control of Hefazat leaders, if the movement refused to leave the BNP. ${ }^{48}$

In March 2017, both a senior Hefazat and a senior BNP leader stated that, owing to a combination of pressure and bribes, the AL had managed to break the IOJ out of the BNP's and make it join its own electoral alliance. ${ }^{49}$ In July 2017, 10 Islamist parties, including the IOJ and a faction of Khilafat Andolan, publicly announced their readiness to join the AL's electoral coalition (Chowdhury 2017). Moreover, as of early 2017, the DGFI and other intelligence services were reportedly negotiating with both the Deobandi parties in Hefazat and other Islamist parties, except the JI, to convince them to form a united electoral platform to weaken the BNP. ${ }^{50}$ As part of these "negotiations," the government reportedly gave between 250 and 500 million taka to various small Islamist 
parties. ${ }^{51}$ In early 2017 , some party leaders and local experts speculated that a united Islamist platform for the 2018/2019 elections might coalesce around the JP of former military dictator Ershad, who has acted as Sheikh Hasina's envoy since 2014. ${ }^{52}$ In July 2017, Ershad announced the formation of the United National Alliance (UNA) between the JP and 57 miniscule Islamist parties. With its postulation of excluding all "anti-liberation quarters," the alliance distanced itself from the JI. Concurrently, it explicitly committed itself to "Bangladeshi nationalism," thereby seeking to coopt the political ideology of the BNP (Bdnews24 5 July 2017). In the long-run, the JP might constitute an attractive coalition partner for the Deobandi parties in Hefazat who reject female leadership and are thus uncomfortable with supporting either the AL or the BNP. ${ }^{53}$

Previous election results, as well as interviews with local experts and political leaders suggest that the capacity of Hefazat and the Deobandi parties to mobilize votes is limited (see also Kabir 2015, 65) and that orthodox voters who sympathize with Hefazat will remain reluctant to vote for the AL. ${ }^{54}$ However, instead of capturing many votes from Hefazat supporters, one of the AL's main motives for co-opting the Deobandi parties is to prevent joint, violent street mobilization by the BNP, the JI, and Hefazat in the run-up to the 2018/2019 elections. As a high-ranking AL leader explained,

Hefazat [followers] will never vote for us. They will never support secular politics. But one thing is to handle them to be much less violent. [...] Indirectly, some people are sitting with them and dialogue with them not to be more violent. ${ }^{55}$

If the JI, the BNP and Hefazat all became more violent, he continued, the situation would become very difficult for the AL to handle. Similarly, press reports indicate that the AL has bribed several Hefazat leaders, including Shafi, to appease them before campaigning starts (Miazee 2017).

Moreover, by co-opting the Deobandi parties, the AL also tries to show to the electorate that it is not "anti-Islamic," while, concurrently, attempting to weaken the JI and divide the BNP's vote bank (Khaled 2017). ${ }^{56}$ As the above-cited AL leader stated

They [Hefazat] are [...] an Islamic fundamentalist group. No doubt about it. And they $[\ldots]$ want to see Bangladesh as an Islamic state. [...] [But] you have to consider election politics. [...] The fractions and divisions 
[among the Islamist parties] we need [them]. This is why we can easily handle the elections. ${ }^{57}$

Thereby, aligning with the Deobandi parties contradicts the AL's political narrative of being the guardian of the independence struggle at least somewhat less than if the party forged an electoral alliance with the JI, because, other than the JI, the Deobandis did not oppose Bangladesh's independence through massacres (Khalidi 2013). However, a high-ranking BNP leader opined that the AL's repression of the JI was primarily due to electoral calculations and if the JI left the BNP, the government's repression of the JI would end immediately, ${ }^{58}$ an assessment that is backed by several experts. ${ }^{59}$

Last but not least, if the 2018/2019 elections were to be free and fiercely contested, the $1 \%$ or $2 \%$ of the votes that might be captured by the Deobandi parties could already make a difference. Currently, however, there are strong indications that the elections will not be free and fair and that the AL might just "literally distribute seats," awarding between 25 and 35 parliamentary seats to Islamist parties other than the JI to weaken the BNP. ${ }^{60}$

The AL's strategy has enhanced, rather than weakened, the BNP's reliance on the JI with its highly disciplined cadres ${ }^{61}$ and leading BNP representatives have publicly committed themselves to maintaining their relations to various Islamist parties (Khaled 2017). As one of them stated frankly, in terms of their co-optation strategies, the "AL and the BNP are the same" and the BNP would also co-opt Hefazat again, if it had a chance. Both the AL and the BNP, he admitted, were acting on the logic that "the enemy of my enemy is my friend," thereby playing "a dirty game" that "is not good for the country." 62

\section{Islamization under the AL: Increasing Authoritarianism, Islamist Radicalization and the Weakening of Secular Opposition to Islamism}

Increasing state repression and the conduct of the 2014 elections without any participation of the opposition have brought Bangladesh closer to authoritarian rule. Concurrently, the lack of a proper electoral mandate has created "paranoia" among the AL's leaders. ${ }^{63}$ Some observers opine that in this context, the AL has begun to use Islamization as a legitimation strategy. ${ }^{64}$ However, the AL's legitimation efforts have often been defensive in that the party has mainly struggled to prove that it is not "antiIslamic." Nevertheless, the AL has made concessions to Islamist forces that have weakened secular opposition to Islamism. 
Since 2013, over 30 atheist and secular bloggers and intellectuals have been killed by extremist groups, with both al-Qaeda and the Islamic State claiming responsibility. While the government has employed security measures to combat terrorism, leading AL representatives have also rebuked secular activists for maligning the Prophet, creating a climate of fear (Graham-Harrison and Hammadi 2016; see also Fazli 2016). Moreover, a prominent human-rights lawyer suggested that the AL exploited the presence of Hefazat, which has publicly threatened human-rights activists, to discourage anti-government criticism by secular actors. The government, she argued, had been very "vicious" against the political opposition, while concurrently being "soft" on Hefazat and portraying itself as the savior of secularism. The AL's strategy, she opined, was to allow Hefazat to keep operating within limits to make secular activists say "oh, thank you, government for keeping them at bay." 65

Furthermore, the AL's handling of the 2013 demonstrations divided the Shahbag movement, which started as a spontaneous gathering of secular bloggers, leftist activists and common citizens. Accusing the government of delaying the war crime trials and conspiring with the JI to save Quader Mollah, the movement was directly critical of the AL in the beginning. ${ }^{66}$ Soon, however, the AL tried to co-opt it. ${ }^{67}$ A major leftist Shahbag leader claimed that bloggers and non-party activists were soon marginalized by the CL and the United Cultural Forum, the AL's student and cultural wings, who "were trained [...] organized and funded for this event." Calling another major Shahbag leader who belonged to the CL a "stooge," he opined that the government had destroyed the non-partisan character of the movement and "betrayed" the Shahbag activists. As the AL co-opted the movement, he lamented, "[o]ur passions and our emotions were used." 68 However, while the CL indeed tried to monopolize the Shahbag movement, ${ }^{69}$ some of its leaders criticized the AL government as well. For instance, the same CL leader who was so bitterly accused by his leftist counterpart emphasized that the Shahbag movement had not only criticized the government's handling of the ICT but also demanded political reforms, such as anti-corruption measures. Citing an episode when both Hefazat activists and state security forces prevented Shahbag activists from protesting in Chittagong, he lamented that the government had "patronized" Hefazat to break the Shahbag movement, which challenged its rule. ${ }^{70}$ Ultimately, the $\mathrm{CL}$ also split into a fraction that was close to, and one that was more independent of the government. ${ }^{71}$

Moreover, to repress the political opposition, the AL is maligning the $\mathrm{BNP}$ as promoting a misguided version of Islam. Leading AL 
representatives have, at least implicitly, accused both the JI and the BNP as being responsible for terrorist activities, including the 2016 Holey Artisan attack (Fazli 2016). A high-ranking AL leader stated that the "BNP [doesn't] believe in secular, democratic politics" and "is encouraging all those people who want to destroy the secular democratic philosophy." Since 2001, he claimed, terrorist activities were committed "sometimes in the name of JI and a major part of BNP also." "72 Similarly, an AL functionary at Dhaka University described the JI as "most fundamentalist" and called both the JI and the BNP "the father of the militant groups," stating that

The emergence of all these [terrorist] groups took place during their [the BNP's and the JI's] rule. [They] used to patronize all this process against the democratic forces. All these extremist groups received patronization from these political parties.

"For becoming a member of the civilized, humanized society," he went on, the AL needed to "crush" all "fundamentalist groups," threating that if the BNP supported any of them it would "also be in trouble." As he concluded, "liberal, democratic society must accommodate others. [...] But not groups that cause threats to humanity," such as the $\mathrm{JI}^{73}$

Moreover, the AL government has instrumentalized the ICT to persecute critics. ${ }^{74}$ By mid-2015, most of the JI's leaders had been hanged, following highly politicized trials. In addition, the JI has faced massive harassment, including torture and forced disappearances, by the state security forces. The repression of the JI could foster radicalization because if the party is driven underground, some of its sympathizers might turn toward more militant groups. Moreover, while the JI pursues the strategy to change society through political means, government repression appears to have reinforced its ideological orthodoxy. ${ }^{75}$ In early 2017 , both a leader and a senior adviser of the JI stated that while the Sharia should only be introduced with the "people's consent" and the introduction of Islamic corporal punishments should only be one step after many others, both nevertheless remained important goals of the party. ${ }^{76}$ As the adviser stated, "if the conditions are there [...] for adultery, 100 leashes should be good, [...] a few hand-cuttings would change the society." 77

The JI leader explained that for the 2018/2019 elections, the party was considering all options, including the formation of a new party under a different name or having some JI members run as independent candidates. ${ }^{78}$ In addition, members of the JI have reportedly begun to infiltrate various 
different parties, including both the AL and the BNP, at the local level, potentially strengthening Islamist tendencies within these parties. ${ }^{79}$

Furthermore, the AL's divide-and-rule tactics might strengthen parties that are ideologically still more radical than the JI. The Deobandi IOJ, which now forms part of the AL's electoral alliance, is a case in point. Under the BNP-led coalition government, the IOJ's chairman Fazlul Haque Amini publicly expressed his sympathy for Osama bin Laden (BBC 27 November 2001), and vowed to make Bangladesh the next Afghanistan. ${ }^{80}$ This distinguishes the IOJ from the JI, whose representatives refer to Rachid Ghannouchi and the Tunisian Ennahda, or the Turkish Adalet ve Kalkınma Partisi (AKP), as role models. ${ }^{81}$

\section{CONCLUSION}

From past to present, the Islamization of public policy in Bangladesh has mostly constituted a top-down process driven by secular ruling parties. Thereby, three main conditions have prompted secular rulers to engage in Islamization: first, the rise of Islamist social movements; second, fierce political competition; and third, (semi-)authoritarian rule. While the Bangladeshi case thus provides support for existing case studies that have pointed to the relevance of these three factors in spurring Islamization by secular rulers, it also furnishes empirical evidence that serves both to clarify the relative explanatory potential of each of these factors and to connect them to each other.

Specifically, it suggests that the presence of Islamist movements alone is not enough to prompt secular rulers to Islamize but does so only when these movements threaten the political survival of secular state leaders in a context marked by political competition and/or semi-authoritarianism. This is exemplified by the AL government's strategy toward Hefazat, which first arose as a counter movement to the party's push for secularization during its early tenure. The AL did not make any concessions to Hefazat following its emergence in 2010 but only from 2013 onwards when the movement's street protests escalated and the AL's main rival, the BNP, sought to exploit its mobilizational potential to topple the government. The AL's concessions to Hefazat have increased as the party's ruling style has turned more authoritarian after the 2014 elections, which did not provide it with proper electoral legitimacy. Concurrently, a historical overview of the Islamization efforts of the military regimes of Zia and Ershad suggests that non-democratic secular rulers may engage in Islamization even when strong 
Islamist movements are absent, indicating that (semi-)authoritarian rule potentially constitutes the strongest driver of Islamization by secular rulers.

In addition, the empirical findings of this article also present three explanations to disentangle the apparent contradiction between the low level of electoral support for Islamist parties and the readiness of consecutive secular governments in Bangladesh to accommodate Islamist forces. Firstly, as the literature already indicates (e.g. Karim and Fair 2007; Riaz 2007a, 2014), both the AL and the BNP have sought to co-opt Islamist parties to win elections under the country's first-past-the-post system. Secondly, the Bangladeshi case also shows, however, that fierce political competition can not only manifest itself in the electoral arena but also through violent street politics. In such a context, secular ruling parties may co-opt Islamist movements that might otherwise increase the street power of their political rivals, even if these movements are largely unrepresentative and unable to mobilize many votes. Thirdly, while Bangladesh's secular traditions remain strong, most Bangladeshis are personally religious, and breaking religious taboos can spark resistance. Hence, the BNP and its allies have repeatedly portrayed the AL as "anti-Islamic," which, in turn, has resorted to Islamization as a defensive legitimation strategy, seeking to prove that this is not the case. This tendency has expanded as the AL's rule has become increasingly authoritarian. With regard to the broader theoretical debate on the extent to which religious ideas, the competition between secular and religious social actors, or the interests of political elites drive religion policy-making (Gill 2008; Fox 2015), these findings show that under conditions of political competition and/or (semi-)authoritarianism, the interest of secular rulers in safeguarding their political survival can serve to multiply the political impact of Islamic religious actors.

Accordingly, the findings of this article also refute alternative explanations that have been raised by foreign diplomats and aid experts and that portray Bangladesh's current Islamization process as the result of an increase in religious orthodoxy in society, a change in the AL's ideology from secularism to Islamism, or both. ${ }^{82}$ This assessment is also backed by the fact that the change in the AL's religion policy, from strengthening secularism to promoting Islamization, has occurred within $<5$ years, whereas religious and ideological convictions are unlikely to change quickly (Gill 2008, 31). However, the AL's Islamization measures may strengthen orthodox Islamic forces in the long-term, particularly if these measures interact with authoritarian government practices that weaken secular opposition to Islamism and strengthen radical Islamist forces through divide-and-rule tactics. 
The findings of this article also have practical implications for foreign and development policy toward Bangladesh. Many foreign diplomats and donors in the country have begun to take social Islamization for granted and now focus on de-radicalization programs and measures to strengthen "moderate Islamic forces." 83 However, unless combined with an in-depth analysis of the real drivers of Islamization, such efforts may weaken the country's secular traditions.

\section{NOTES}

1. Interview: senior journalist, Dhaka, 12.03.2017.

2. For another study on this topic, see Buehler's (2013) analysis of Indonesia. Other than this article, however, it focuses on the provincial level.

3. This definition differs from Ismail's in its focus on the political process. Ismail also refers to Islamization as a social process, which includes various forms of religious piety, such as the wearing of the hijab (veil) (Ismail 2006, esp. 2).

4. See Ahamed and Nazneen (1990, 796-799); Karim and Fair $(2007,5)$ on this latter point.

5. Interview: BNP leader, Dhaka, 11.03.2017.

6. Interview: JI leader, Dhaka, 06.03.2017.

7. Interview: JI adviser, Dhaka, 04.03.2017.

8. Interview: embassy expert, Dhaka, 08.03.2017; see also Siddiqi $(2011,13,19)$.

9. Interview: embassy expert, Dhaka, 08.03.2017.

10. Interview: embassy expert, Dhaka, 08.03.2017.

11. Interview: embassy expert, Dhaka, 08.03.2017.

12. Interview: Dhaka University (DU) expert, Dhaka, 05.03.2017.

13. Interview: UN representative, Dhaka, 09.03.2017.

14. Interview: BNP leader, Dhaka, 11.03.2017.

15. Interview: BNP leader, Dhaka, 11.03.2017.

16. Interview: senior journalist close to the AL, Dhaka, 12.03.2017.

17. Interview: Hefazat leader, Dhaka, 11.03.2017.

18. Interviews: JI adviser, Dhaka, 04.03.2017; telephone, JI leader, 27.02.2017.

19. Interview: Hefazat leader, Dhaka, 11.03.2017.

20. Interview: Shahbag activists, Dhaka, 11.03.2017.

21. Interview: Hefazat leader, Dhaka, 11.03.2017.

22. Interview: Hefazat leader, Dhaka, 11.03.2017.

23. Interviews, Dhaka: UN representative, 09.03.2017; senior journalist, 05.03.2017.

24. Interview: UN representative, Dhaka, 09.03.2017

25. Interview, Dhaka, 07.03.2017.

26. Interview: local NGO expert, Dhaka, 11.03.2017.

27. Interview, Dhaka, 07.03.2017.

28. Interviews, Dhaka: DU expert, 05.03.2017; embassy expert, 08.03.2017; local NGO expert, 11.03.2017.

29. Interviews Dhaka: Western diplomats, 08.03.2017; 13.03.2017; UN representative, 09.03.2017; see also Islam (2016: 64).

30. Interview: JI leader, Dhaka, 06.03.2017.

31. Interview: Shahbag and Chattra League (CL) leader, Dhaka, 11.03.2017.

32. Interview: Shahbag and CL leader, Dhaka, 11.03.2017.

33. Interview: terrorism expert, Dhaka, 04.03.2017.

34. Interview: terrorism expert, Dhaka, 04.03.2017.

35. Interview: embassy expert, Dhaka, 08.03.2017.

36. Interview: senior journalist, Dhaka, 07.03.2017.

37. Interviews senior journalist: telephone, 26.02.2017; Dhaka, 05.03.2017.

38. Interviews, Dhaka: Hefazat leader, 11.03.2017; BNP leader, 11.03.2017.

39. Interview: Bangladeshi consultant, Berlin, 02.03.2017. 
40. Interview: Hefazat leader, Dhaka, 11.03.2017.

41. Interviews, Dhaka: DU expert, 05.03.2017; embassy expert, 08.03.2017; terrorism expert, 04.03.2017; NGO legal expert, 09.03.2017; interview, Dhaka, 07.03.2017.

42. Interview: Hefazat leader, Dhaka, 11.03.2017.

43. Interview: expert scholar, 13.03.2017.

44. Interview: senior journalist, Dhaka, 12.03.2017.

45. Interviews, Dhaka: embassy expert, 08.03.2017; Hefazat leader, 11.03.2017.

46. Interview: BNP leader, Dhaka, 11.03.2017.

47. Interviews, Dhaka, 11.03.2017: BNP-leader; Hefazat leader.

48. Interview: Hefazat leader, Dhaka, 11.03.2017.

49. Interviews, Dhaka, 11.03.2017: BNP-leader; Hefazat leader; see also interview: local NGO expert, Dhaka, 11.03.2017.

50. Interviews, Dhaka, 11.03.2017: Hefazat leader; senior journalist.

51. Interview: senior journalist, Dhaka, 11.03.2017.

52. For example, interviews, Dhaka, 11.03.2017: BNP leader; local NGO expert.

53. Interview: Hefazat leader, Dhaka, 11.03.2017.

54. Interviews, Dhaka: embassy expert, 08.03.2017; AL leader, 07.03.2017; local NGO expert, 11.03.2017.

55. Interview: AL leader, Dhaka, 07.03.2017.

56. Interviews, Dhaka: embassy expert, 08.03.2017; local NGO expert, 11.03.2017.

57. Interview: AL leader, Dhaka, 07.03.2017.

58. Interview: BNP leader, Dhaka, 11.03.2017.

59. For example, interview: embassy expert, Dhaka, 08.03.2017; interview, Dhaka, 07.03.2017.

60. Interviews, Dhaka: local NGO expert, 11.03.2017; senior journalist, 12.03.2017.

61. Interviews, Dhaka: JI leader, 06.03.2017; BNP leader, 11.03.2017.

62. Interview: BNP leader, Dhaka, 11.03.2017.

63. Interview: UN representative, Dhaka, 09.03.2017; interview, Dhaka, 07.03.2017.

64. For example, interviews, Dhaka: DU professor, 05.03.2017; BNP leader, 11.03.2017.

65. Interview: NGO legal expert, Dhaka, 09.03.2017.

66. Interviews, Dhaka: Shabagh and CL leader, 11.03.2017; leftist Shabagh leader, 13.03.2017.

67. Interviews, Dhaka: DU professor, 05.03.2017; Shabagh activists, 09.03.2017.

68. Interview: leftist Shabagh leader, Dhaka, 13.03.2017.

69. Interviews, Dhaka: DU professor, 05.03.2017; senior journalist, 13.03.2017.

70. Interview: Shahbag and CL leader, Dhaka, 11.03.2017.

71. Interview: DU professor, Dhaka, 05.03.2017.

72. Interview: AL leader, Dhaka, 07.03.2017.

73. Interview: AL functionary, DU, Dhaka, 07.03.2017.

74. Interview: INGO representative, Berlin, 30.04.2015.

75. Interview: embassy expert, Dhaka, 08.03.2017; interview, Dhaka, 07.03.2017.

76. Interviews, Dhaka: JI adviser, 04.03.2017; JI leader, 06.03.2017.

77. Interview: JI adviser, Dhaka, 04.03.2017.

78. Interview: JI leader, Dhaka, 06.03.2017.

79. Interviews: senior journalist, Dhaka 06.03.2017; interview, Dhaka, 07.03.2017.

80. Interview: local NGO expert, Dhaka, 11.03.2017.

81. Interviews: JI adviser, Dhaka, 04.03.2017; telephone, JI leader, 27.02.2017.

82. Interviews, Dhaka: foreign embassy representatives, 08.03.2017, 13.03.2017; UN representative, 09.03.2017.

83. Interview: INGO representative, Berlin, 16.02.2017.

\section{REFERENCES}

Abbott, Jason, and Sophie Gregorios-Pippas. 2010. "Islamization in Malaysia: Processes and Dynamics." Contemporary Politics 16(2):135-51.

Ahamed, Emajuddin, and D.R.J.A. Nazneen. 1990. "Islam in Bangladesh: Revivalism or Power Politics?" Asian Survey 30(8):795-808. 
Ahsan, Zayadul, and Pavitra Banavar. 2011. "Who are the Militants?" In Political Islam and Governance in Bangladesh, eds. Ali Riaz and C. Christine Fair. Oxon: Routledge, 46-70.

AL (Awami League) Constitution. https://www.albd.org/ parbonc/index.php/en/party/ constitution (Accessed October 21, 2017).

Asseburg, Muriel. 2007. "Einführung." In Moderate Islamisten als Reformakteure. Rahmenbedingungen und pragmatischer Wandel, ed. Muriel Asseburg. Berlin: Stiftung Wissenschaft und Politik (SWP), 9-11.

Barr, Ellen, and Julfikar A. Manik. 2017. "To Secular Bangladeshis, Textbook Changes Are a Harbinger." New York Times. 22 January. https://www.nytimes.com/2017/01/ 22/world/asia/bangladesh-textbooks-radical-islam.html (Accessed October 21, 2017).

BBC. 27 November 2001. "Bangladesh and the Bin Laden Cult." http://news.bbc.co.uk/2/ hi/south_asia/1669116.stm (Accessed October 21, 2017).

BBC. 6 May 2017. "Clashes over Bangladesh Protest Leave 27 Dead." http://www.bbc. com/news/world-asia-22423815 (Accessed October 21, 2017).

Bdnews24. 13 April 2017. "Government Publishes Gazette on Highest Qawmi Madrasa Degree Cognition." https://bdnews24.com/bangladesh/2017/04/13/govt-publishes-gazetteon-highest-qawmi-madrasa-degree-recognition (Accessed October 21, 2017).

Bdnews24. 5 July 2017. "Ershad Launches Jatiya Party-led Alliance." https://bdnews24.com/ politics/2017/05/07/ershad-launches-jatiya-party-led-alliance (Accessed October 21, 2017).

Bouissou, Julien. 2013. "Bangladesh's Radical Muslims Uniting behind Hefazat-e-Islam," The Guardian. 30 July. https://www.theguardian.com/world/2013/jul/30/bangladeshhefazat-e-islam-shah-ahmad-shafi (Accessed October 21, 2017).

BSoPO (Bangladesh Survey of Public Opinion). 2016. http://www.iri.org/sites/default/ files/wysiwyg/iri_survey_of_bangladesh_public_opinion_-_february_2016_-_public.pdf (Accessed May 12, 2018).

Buehler, Michael. 2013. "Subnational Islamization through Secular Parties: Comparing Shari'a Politics in Two Indonesian Provinces." Comparative Politics 46(1):63-82.

Butt, Ahsan I. 2016. "Street Power: Friday Prayers, Islamist Protests, and Islamization in Pakistan." Politics and Religion 9:1-28.

Camroux, David. 1996. "State Responses to Islamic Resurgence in Malaysia: Accommodation, Co-optation, and Confrontation." Asian Survey 36(9):852-68.

Chowdhury, Moinul Haque. 2017. "New Islamist Alliance Seeks to Ride on Awami League in Next Election." Bdnews24. 29 July. https://bdnews24.com/politics/2017/07/29/new-islamistalliance-seeks-to-ride-on-awami-league-in-next-election (Accessed October 21, 2017).

Codron, Jérémie. 2007. "Putting Factions 'Back in' the Civil-Military Relations Equation: Genesis, Maturation and Distortion of the Bangladeshi Army." South Asia Multidisciplinary Academic Journal, 18 October 2007. https://samaj.revues.org/230 (Accessed October 21, 2017).

Daily Star. 23 December 2008. "Vote for BNP to Save Islam. Khaleda Tells Sylhet Rallies." http://www.thedailystar.net/news-detail-68349 (Accessed October 21, 2017).

Daily Star Lebanon. 16 February 2016. "Bangladesh Arrests Publisher for 'Offensive Book' on Islam.” http://www.dailystar.com.lb/News/World/2016/Feb-16/337490bangladesh-arrests-publisher-for-offensive-book-on-islam.ashx (Accessed July 2, 2018).

D'Costa, Bina. 2007. "Faith Based NGOs and the Politics of Secularism in Bangladesh". In Civil Society, Religion and Global Governance, ed. Helen James. Oxon: Routledge, 219-38.

Dhurba, Golam M. 2017. "Bangla Academy Alerts Police on 'Religion Sensitive' Books at Ekushey Book Fair." Bdnews24.com. 30 January. https://bdnews24.com/bangladesh/ 2017/01/30/bangla-academy-alerts-police-on-religion-sensitive-books-at-ekushey-bookfair (Accessed October 21, 2017).

Donker, Teije Hidde. 2013. "Re-emerging Islamism in Tunisia: Repositioning Religion in Politics and Society." Mediterranean Politics 17(3):285-302. 
Express Tribune. 16 February 2017. "Bangladesh Arrests Publisher for 'Offensive' Book on Islam.” https://tribune.com.pk/story/1047839/bangladesh-arrests-publisher-for-offensivebook-on-islam/ (Accessed October 21, 2017).

Fair, C. Christine, Ali Hamza, and Rebecca Heller. 2017. "Who Supports Suicide Terrorism in Bangladesh. What the Data Say." Politics and Religion 10(30):622-61.

Fazli, Shehryar. 2016. "Bangladeshi Leaders Must Stop Politicizing Counterterrorism," ICG Op-ed. https://www.crisisgroup.org/asia/south-asia/bangladesh/bangladeshileaders-must-stop-politicizing-counterterrorism (Accessed October 21, 2017).

Fox, Jonathan. 2015. Political Secularism, Religion, and the State. A Time Series Analysis of Worldwide Data. New York: Cambridge University Press.

Freedman, Amy L. 2009. "Political Viability, Contestation and Power: Islam and Politics in Indonesia and Malaysia." Politics and Religion 2:100-127.

Gill, Anthony. 2008. The Political Origins of Religious Liberty. New York: Cambridge University Press.

Ghanem, Hafez. 2013. Will Tunisia Follow Egypt? Brookings OP-Ed. 25 July 2013. https://www.brookings.edu/opinions/will-tunisia-follow-egypt/ (Accessed October 21, 2017).

Graham-Harrison, Emma, and Saad Hammadi. 2016. "Inside Bangladesh's Killing Fields: Bloggers and Outsiders Targeted by Fanatics." The Guardian. 12 June. https://www. theguardian.com/world/2016/jun/11/bangladesh-murders-bloggers-foreigners-religion (Accessed October 21, 2017).

Hamid, Shadi. 2014. Temptations of Power. Islamists and Illiberal Democracy in a New Middle East. New York: Oxford University Press.

Hashmi, Arshi Saleem. 2016. "Historical Roots of the Deobandi Version of Jihadism and Its Implications for Violence in Today's Pakistan." In Faith-Based Violence and Deobandi Militancy in Pakistan, eds. Syed et al. London: Palgrave Macmillan, 133-162.

ICG (International Crisis Group). 2006. Bangladesh Today, ICG Asia Report No 121. Brussels: ICG.

ICG. 2012. Bangladesh: Back to the Future, ICG Asia Report No 226. Brussels: ICG.

Ismail, Salwa. 2006. Rethinking Islamist Politics. Culture, the State and Islamism. London: I.B. Tauris.

Islam, S. Nazrul. 2016. Governance for Development: Political and Administrative Reforms in Bangladesh. Houndmills, Basingstoke: Palgrave Macmillan.

Jahan, Ferdous, and Asif M. Shahan. 2014. "Power and Influence of Islam-Based Political Parties in Bangladesh: Perception Versus Reality." Journal of African and Asian Affairs 49(4):426-41.

Kabir, Humayun. 2015. "Beyond the Jamaat-e-Islami: The Political Rise of the Deobandis, the Mystic Leaders, and Islamism in Bangladesh." In Religion and Representation. Islam and Democracy, eds. Ingrid Mattson, Paul Nesbitt-Larking, and Nawaz Tahir. Cambridge: Cambridge Scholars Publishing, 50-77.

Khaled, Sarwar Md. Saifullah. 2017. "Islamic Parties and Elections." The Independent. 31 May. http://www.theindependentbd.com/post/97159 (Accessed October 21, 2017).

Khalidi, Toufique Imrose. 2013. "Behind the Rise of Bangladesh's Hifazat. Group that triggered deadly protests has surprised many with its rise to prominence." Al Jazeera. 9 May. https://www.aljazeera.com/indepth/features/2013/05/201356134629980318.html (Accessed June 25, 2018).

Khan, Karim. 2013. "Distributive Consideration in Institutional Change: The Case of Zia's Islamization Policy in Pakistan." Constitutional Political Economy 24:139-65.

Karim, A. Tariq, and C. Christine Fair. 2007. Bangladesh at the Crossroads, United States Institute of Peace (USIP) Special Report No. 181. Washington DC: United States Institute for Peace (USIP). 
Kubicek, Paul. 2015. Political Islam and Democracy in the Muslim World. Boulder: Lynne Rienner.

Kugelman, Michael, and Atif Ahmad. 2017. "Why Terrorism is on the Rise in Bangladesh." Foreign Affairs. 27 July. https://www.foreignaffairs.com/articles/asia/ 2017-07-27/why-extremism-rise-bangladesh (Accessed October 21, 2017).

Levitsky, Steven, and Lucan A. Way. 2002. "Elections without Democracy: The Rise of Competitive Authoritarianism." Journal of Democracy 13(2):51-65.

Liow, Joseph Chinyong. 2004. "Political Islam in Malaysia: Problematising Discourse and Practice in the UMNO-PAS 'Islamisation Race'." Commonwealth \& Comparative Politics 42(2):184-205.

Lorch, Jasmin. 2014. "Elections in Bangladesh: Political Conflict and the Problem of Credibility." E-International Relations. 2 February. http://www.e-ir.info/2014/02/02/ elections-in-bangladesh-political-conflict-and-the-problem-of-credibility/ (Accessed October 21, 2017).

Malik, Hafeez. 1986. "Martial Law and Islamization in Pakistan." Orient 27(4):583-605.

Martin, Vanessa. 2007. Creating an Islamic State. Khomeini and the Making of a New Iran. London: I.B. Tauris.

Masud, Kazi Anwarul. 2006. "Religious Education and Politics." The Daily Star. 27 August. http://archive.thedailystar.net/2006/08/27/d60827020421.htm (Accessed October 21, 2017).

Mechan, Quinn, and Julie C. Hwang. 2014. "Introduction: The Emergence and Development of Islamist Political Parties." In Islamist Parties and Political Normalization in the Muslim World, eds. Quinn Mechan and Julie C. Hwang. Pennsylvania: Pennsylvania University Press, 1-16.

Miazee, Manik. 2017. "Who Calls the Shots in Hefazat Now?" Dhaka Tribune. 19 September. http://www.dhakatribune.com/bangladesh/politics/2017/09/19/calls-shotshefazat-now/ (Accessed October 21, 2017).

Milam, William B. 2007. "Bangladesh and the Burdens of History." Current History 106 (699):153-60.

New Age. 19 September 2013. "Nielsen/Democracy International Polls on Bangladesh". http://bangladeshpolitico.blogspot.de/2013/09/nielsendemocracy-international-polls-on. html (Accessed May 12, 2018).

Ottaway, Marina. 2003. Democracy Challenged. The Rise of Semi-Authoritarianism. Washington DC: Carnegie.

Parmentier, Mary Jane C. 1999. "Secularization and Islamisation in Morocco and Algeria." The Journal of North African Studies 4(4):27-50.

Riaz, Ali. 2007a. "Bangladesh." In Islamist Opposition Parties and the Potential for EU Engagement, eds. Toby Archer and Heidi Huuhtannen. Helsinki: Ulkopoliittinen instituutti (UPI), 25-34.

Riaz, Ali. 2007b. Islamist Militancy in Bangladesh. A Complex Web. London: Routledge.

Riaz, Ali. 2014. "Islamist Parties, Elections and Democracy in Bangladesh." In Islamist Parties and Political Normalization in the Muslim World, eds. Quinn, Mechan and Julie, C. Hwang. Pennsylvania: Pennsylvania University Press, 156-74.

Riaz, Ali, and C. Christine Fair. 2011. Political Islam and Governance in Bangladesh. Oxon: Routledge.

Schwedler, Jillian. 2011. "Can Islamists Become Moderates? Rethinking the InclusionModeration Hypothesis." World Politics 63(2):347-76.

Siddiqi, Dina M. 2011. "Political Culture in Contemporary Bangladesh: Histories, Ruptures and Contradictions." In Political Islam and Governance in Bangladesh, eds. Ali, Riaz and C. Christine Fair. Oxon: Routledge, 7-26. 